\title{
Is Forced Swimming Immobility a Good Endpoint for Modeling Negative Symptoms of Schizophrenia? - Study of Sub-Anesthetic Ketamine Repeated Administration Effects
}

\author{
GILDA NEVES, MILENE BORSOI, CAMILA B. ANTONIO, MARIANA \\ A. PRANKE, ANDRESA H. BETTI and STELA M.K. RATES \\ Laboratório de Psicofarmacologia Experimental, Faculdade de Farmácia, Universidade Federal \\ do Rio Grande do Sul, Av. Ipiranga, 2752, 90610-000 Porto Alegre, RS, Brazil
}

Manuscript received on December 12, 2016; accepted for publication on March 16, 2017

\begin{abstract}
Immobility time in the forced swimming has been described as analogous to emotional blunting or apathy and has been used for characterizing schizophrenia animal models. Several clinical studies support the use of NMDA receptor antagonists to model schizophrenia in rodents. Some works describe the effects of ketamine on immobility behavior but there is variability in the experimental design used leading to controversial results. In this study, we evaluated the effects of repeated administration of ketamine subanesthetic doses in forced swimming, locomotion in response to novelty and novel object recognition, aiming a broader evaluation of the usefulness of this experimental approach for modeling schizophrenia in mice. Ketamine (30 mg/kg/day i.p. for 14 days) induced a not persistent decrease in immobility time, detected $24 \mathrm{~h}$ but not $72 \mathrm{~h}$ after treatment. This same administration protocol induced a deficit in novel object recognition. No change was observed in mice locomotion. Our results confirm that repeated administration of sub-anesthetic doses of ketamine is useful in modeling schizophrenia-related behavioral changes in mice. However, the immobility time during forced swimming does not seem to be a good endpoint to evaluate the modeling of negative symptoms in NMDAR antagonist animal models of schizophrenia.
\end{abstract}

Key words: antidepressant-like effect, immobility behavior, locomotor activity, memory negative symptoms.

\section{INTRODUCTION}

Immobility time in the forced swimming was first described by Porsolt et al. (1977) as behavioral despair and originated one of the most recognized and useful animal tasks for screening potential antidepressant drugs. In addition to its association with depressive symptoms, an increase in immobility time has been also considered a successful strategy for dealing with stress. It has been

Correspondence to: Gilda Neves

E-mail: ganeves@icb.ufrj.br proposed that after repeated swimming animals learn that move is useless and become immobile faster and for a longer period for saving energy (Borsini et al. 1986, de Kloet and Molendijk 2016, Masuda et al. 2001, Parra et al. 1999, West 1990). However, studies showing a deleterious effect of the repeated forced swim on cognitive tasks, such as the Morris water maze (Abel and Hannigan 1992, Rates 1998), novel object recognition (Yuen et al. 2012), object location (Borsoi et al. 2015a) and prepulse inhibition tests (Borsoi et al. 2015a, b), 
contradict this successful strategy theory. On the other hand, immobility behavior in the forced swimming has been also related to schizophrenia negative symptoms, as apathy and lack of initiative (Langen et al. 2012, Noda et al. 1995, Porsolt et al. 2010).

One of the most studied pharmacological animal models of schizophrenia uses N-methyl-D-aspartate receptor (NMDAR) noncompetitive antagonists administration to rodents. These models are based on several pharmacological, genetic and post-mortem studies that strongly suggest an important role for NMDAR hypofunction in the pathophysiology of schizophrenia (Coyle 2012, Kantrowitz and Javitt 2012, Pilowsky et al. 2006). In healthy volunteers, the noncompetitive NMDAR antagonist ketamine induces effects similar to positive and negative schizophrenia symptoms as well as cognitive dysfunctions (Adler et al. 1999). Furthermore, schizophrenic patients treated with this drug present an exacerbation of psychosis (Lahti et al. 1995). These and several other evidence support the proposition of the hypoglutamatergic hypothesis of schizophrenia and the use of NMDAR antagonists to model this psychiatric disorder in animals.

The NMDAR antagonist most used to model schizophrenia in rodents is phencyclidine (PCP). Noda et al. (1995) reported that repeated administration of PCP $(10 \mathrm{mg} / \mathrm{kg} /$ day s.c., 14 days $)$ to mice was able to increase the immobility of animals when exposed to forced swimming until 21 days after stopping treatment. According to authors, this behavior can be associated to negative symptoms of schizophrenia, as lack of initiative, apathy or emotional blunting. Atypical antipsychotics, such clozapine and risperidone, are able to reverse the pro-immobility effect induced by PCP repeated administration (Corbett et al. 1999, Mouri et al. 2012, Murai et al. 2007, Noda et al. 1995, 1997). Similar results were described after repeated administration of another NMDAR antagonist, MK-801 $(0.2 \mathrm{mg} / \mathrm{kg} / \mathrm{day}$ for 15 days i.p.): an increase on the immobility time which was blocked by antipsychotics administration (Kawaura et al. 2015, 2016, Langen et al. 2012, Rundfeldt et al. 2000). These data lead to the use of the increase in the immobility time in the forced swimming as a tool to evaluate affective flattening in schizophrenia animal models (Neill et al. 2014) and even for the development of new drug candidates (Porsolt et al. 2010).

Besides PCP and MK-801, ketamine has also been used to model schizophrenia symptoms in rodents (Adler et al. 1999, Bubenikova-Valesova et al. 2008, Large 2007). This drug is able to induce hyperlocomotion, stereotypy, as well as deficits in attentional and memory processes in rodents (Chan et al. 2008, Imre et al. 2006, Neves et al. 2013, Pietersen et al. 2007, Pitsikas et al. 2008, Rodvelt et al. 2008, Wang et al. 2006). Becker et al. (2003) and Becker and Grescksch (2004) showed that a sub-anesthetic dose of ketamine $(30 \mathrm{mg} / \mathrm{kg} /$ day i.p.) administered for 5 days reduced the non-aggressive social behavior in rodents, a sign that can be associated to schizophrenia negative symptoms.

Few studies describe the effects of ketamine repeated administration on the immobility behavior in the forced swimming and the results are controversial. Some authors characterized an increase in the immobility as a behavior related to apathy (Chatterjee et al. 2011, Chindo et al. 2012, Hou et al. 2013), while others showed a decrease on this behavior (Akinfiresoye and Tizabi 2013, Garcia et al. 2008b, Owolabi et al. 2014, Parise et al. 2013, Popik et al. 2008, Tizabi et al. 2012) probably related to the described rapid antidepressant effect of this drug (Rot et al. 2010, Zarate et al. 2006). In a recent review, Neill et al. (2014) discuss this issue and highlight the necessity of more studies to achieve a better understanding of schizophrenia symptoms modeling by NMDAR antagonists using behavioral tasks associated to anhedonia and emotional blunting, especially in mice. Thus, in this work we investigated the effects of repeated administration of sub-anesthetic doses of ketamine in the forced swimming paradigm. Locomotion in response to novelty and novel object recognition (tasks related to positive and cognitive impairments presented by schizophrenia patients, respectively) were also performed in order to make a broader evaluation. 


\section{MATERIALS AND METHODS}

\section{ANIMALS}

Adult CF1 male mice $(25$ - $35 \mathrm{~g})$ from Fundação Estadual de Produção e Pesquisa em Saúde do Rio Grande do Sul breeding colony were used. Animals were housed in groups in plastic cages $(17 \times 28 \times$ $13 \mathrm{~cm}, 6$ mice per cage) with free access to food (Nuvital ${ }^{\circledR}$ ) and water. Mice were kept at constant room temperature $\left(22 \pm 2{ }^{\circ} \mathrm{C}\right)$ and humidity $(60 \%)$, under a $12 \mathrm{~h}$ light-dark cycle (lights off at 7:00 pm) and were adapted to local conditions for at least $72 \mathrm{~h}$ before the experiments. All procedures were previously approved by the local Animal Care Ethical Committee (CEUA-UFRGS; approval number 2006541) and performed according to Brazilian guidelines (Brasil 2013) and to Directive of the European Parliament and of the Council of the European Union of 22 September 2010 (2010/63/EU).

\section{DRUGS}

$S(+)$-Ketamine hydrochloride (kindly supplied by Cristália ${ }^{\circledR}$, São Paulo, Brazil) was used in this study. The drug was dissolved directly in saline $(\mathrm{NaCl}$ $0.9 \%$ ) and was administered by intraperitoneal route in a volume of $1 \mathrm{~mL} / 100 \mathrm{~g}$ body weight. Vehicle groups received saline. Ketamine doses are expressed as salt.

\section{FORCED SWIMMING}

The methodology used was based on that described by Noda et al. $(1995,1997)$ with some modifications according to the standard protocol used by our group (Viana et al. 2008, Borsoi et al. 2015a, b). Animals were habituated to laboratory conditions one hour before exposition to the forced swimming session. The room was maintained at $23 \pm 2{ }^{\circ} \mathrm{C}$, under artificial lighting. Mice were forced to swim for $3 \mathrm{~min}$ in transparent acrylic recipients $(15 \times 15 \times 30 \mathrm{~cm})$ containing water up to
$15 \mathrm{~cm}$ depth at $21 \pm 1{ }^{\circ} \mathrm{C}$. At the end of the session, animals were removed from the water and gently dried. The measurement of animals' immobility (seconds) was performed by trained observers blind to the treatments. A mouse was considered immobile when it remained floating making only the movements necessary to keep its head above the water. All forced swimming sessions occurred between 10 a.m. and 3 p.m.

\section{LOCOMOTOR ACTIVITY IN RESPONSE TO NOVELTY}

Locomotor activity was measured in an rectangular acrylic arena $(30 \times 30 \times 45 \mathrm{~cm}$, transparent walls and black floor divided into 24 squares of equal area) completely novel to animals. Mice were allowed to freely explore the arena during 15 minutes. A trained observer unaware of the treatments recorded the total number of squares crossings, rearings and groomings during exploration period.

\section{NOVEL OBJECT RECOGNITION}

The novel object recognition task was performed in the same arena used for locomotion study. Animals were submitted to three experimental trials. Initially, mice were placed in the empty arena for $10 \mathrm{~min}$ (habituation session). In the acquisition trial (trial 1 - performed $24 \mathrm{~h}$ after the habituation session), animals were replaced in the same arena containing two identical objects (objects A) for $10 \mathrm{~min}$ and left to freely explore them. Exploration was defined as the animal directing the nose to the object while looking at, sniffing or touching it. Ninety minutes later, a second trial was performed (trial 2 - short term memory test). Animals were placed back in the arena for 10 min and an unknown object (object B) replaced one of the objects presented in the first trial. The total time spent exploring each object was determined by an observer unaware of the treatments. The long term memory test (trial 3) was carried out $24 \mathrm{~h}$ after the acquisition trial. In this last trial a third object was presented to animals as the novel object (object $C$ ) together with the familiar one (object A) and again the total time spent in exploration 
of each object was determined. The recognition index in each session was calculated as: time exploring the novel object / time exploring the novel object + time exploring the familiar object. The objects were similar in size, color, made of the same material but different in shapes. The arena and the objects were cleaned between each trial using ethanol $10 \%$ to avoid odor trails. All procedures were done in a room dimly lit (15 lux).

EXPERIMENT 1: EFFECT OF DIFFERENT DOSES AND PERIODS OF KETAMINE TREATMENT IN THE FORCED SWIMMING

On the first day (day 1), mice were exposed to forced swim as described at subsection Forced swimming. On the following day (day 2), the animals were randomly distributed into three different groups: vehicle (treated with saline $1 \mathrm{~mL} / 100 \mathrm{~g}$ body weight i.p.), ketamine 30 (treated with ketamine $30 \mathrm{mg} / \mathrm{kg} /$ day i.p.) and ketamine 45 (treated with ketamine $45 \mathrm{mg} / \mathrm{kg} /$ day i.p.). Ketamine doses were selected based on literature data (Becker et al. 2003, Becker and Grescksch 2004). Treatments were given once a day from the $2^{\text {nd }}$ to the $15^{\text {th }}$ day. Twentyfour hours after the last treatment $\left(16^{\text {th }}\right.$ day), animals were forced to swim once again.

In order to identify the best treatment length, a similar schedule was performed. On the first day, mice were forced to swim as described at subsection Forced swimming. On the following day, animals were randomly distributed into four different groups: vehicle (treated with saline 1 $\mathrm{mL} / 100 \mathrm{~g}$ body weight i.p. for 14 days), ketamine 1 day (treated with saline $1 \mathrm{~mL} / 100 \mathrm{~g}$ i.p. for 13 days and with ketamine $30 \mathrm{mg} / \mathrm{kg}$ i.p. for 1 day), ketamine 5 days (treated with saline $1 \mathrm{~mL} / 100 \mathrm{~g}$ i.p. for 9 days and with ketamine $30 \mathrm{mg} / \mathrm{kg}$ i.p. for 5 days) and ketamine 14 days (treated with ketamine $30 \mathrm{mg} / \mathrm{kg} /$ day i.p. for 14 days). Twenty-four hours after the last treatment ( $16^{\text {th }}$ day), the animals were forced to swim once again.

Finally, the persistence of ketamine's effect on the forced swimming was evaluated as follow: mice were forced to swim as described at subsection
Forced swimming. On the following day, animals were randomly distributed into two different groups: vehicle (treated with saline $1 \mathrm{~mL} / 100 \mathrm{~g}$ body weight i.p. for 14 days), ketamine (treated with ketamine $30 \mathrm{mg} / \mathrm{kg} /$ day i.p. for 14 days). After this period, animals were exposed to forced swimming again at the following days: $16^{\text {th }}, 18^{\text {th }}$, $22^{\text {nd }}, 29^{\text {th }}$ and $36^{\text {th }}$, i.e. one, three, seven, fourteen and twenty-one days after treatment. A scheme of the experimental schedules described is presented in Figure 1a.

\section{EXPERIMENT 2: KETAMINE REPEATED TREATMENT EFFECT ON LOCOMOTION AND NOVEL OBJECT RECOGNITION}

On the first day, mice were exposed to forced swimming as described at subsection Forced swimming. On the following day, the animals were randomly distributed into three different groups: sham (mice only gently handled for 14 days), vehicle (treated with saline $1 \mathrm{~mL} / 100 \mathrm{~g}$ body weight i.p. for 14 days) and ketamine (treated with ketamine $30 \mathrm{mg} / \mathrm{kg} /$ day i.p. for 14 days). Twentyfour hours later $\left(16^{\text {th }}\right.$ day), the animals spontaneous locomotion were evaluated as described at subsection Locomotor activity in response to novelty and immediately forced to swim for a second time. The novel object recognition procedure started $24 \mathrm{~h}$ after the last swimming session and was carried out as described at subsection Novel object recognition. A scheme of the experimental schedule described above is presented in Figure $1 \mathrm{~b}$.

\section{STATISTICAL ANALYSIS}

Data are expressed as mean \pm S.E.M. Firstly, all datasets were tested for their normal distribution (Shapiro-Wilk test) and homogeneity of variances (Brown-Forsythe test). Thus, the following statistical tests were employed: Students t test (paired and unpaired), one way analysis of variance (ANOVA) followed by Student-Newman-Keuls post hoc test, two-way repeated-measures analysis 


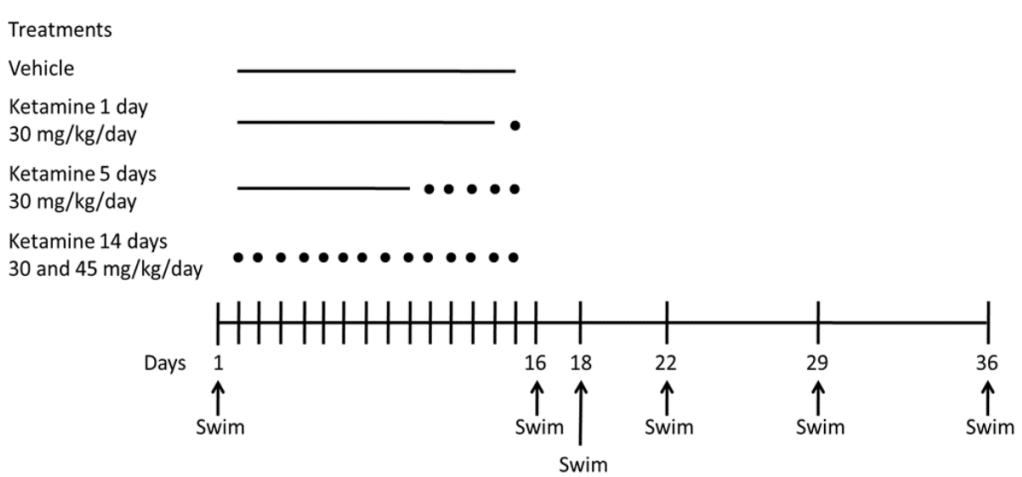

b

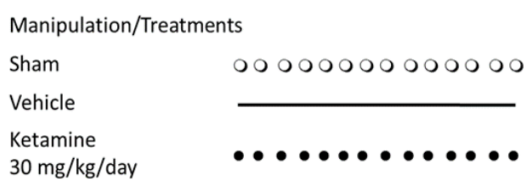

$30 \mathrm{mg} / \mathrm{kg} / \mathrm{day}$

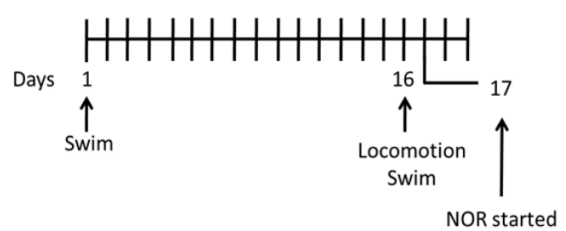

Figure 1 - Experimental schedules used in this work. a) Evaluation of the effect of different doses and periods of treatment with ketamine on the immobility of animals exposed to forced swim. b) Evaluation of ketamine repeated treatment on locomotion and novel object recognition task. o Gentle handling; - vehicle administration (saline 1 $\mathrm{mL} / 100 \mathrm{~g}$ body weight i.p.); • ketamine administration (i.p.).

of variance ANOVA followed by Student-NewmanKeuls post hoc test. Tests were selected according to experimental design, the number of datasets and the number of factors to be analyzed. Analyses were performed using Sigma Stat 2.03 software (Jandel Scientific Corporation). Differences were considered statistically significant at $p<0.05$.

\section{RESULTS}

EFFECT OF DIFFERENT DOSES AND PERIODS OF KETAMINE'S TREATMENT ON THE FORCED SWIMMING

At first, the effects of two different doses of ketamine on the forced swimming were evaluated:
30 and $45 \mathrm{mg} / \mathrm{kg} /$ day for 14 days. The two-way repeated-measures ANOVA revealed a significant day influence on immobility time and an interaction between treatment and day (treatment: $F_{(2,29)}=0.987, p=0.385$; day: $F_{(1,29)}=24.435, p$ $<0.001$; treatment versus day interaction: $F_{(2,29)}$ $=6.874, p=0.004)$. The experimental groups did not differ on the immobility behavior in the first experimental day, i.e., before starting any treatment (Student-Newman-Keuls post-hoc test, $p>0.331$ ). The lowest ketamine dose evaluated induced a significant decrease in animals immobility time on the second exposition to the forced swimming procedure (Student-Newman-Keuls post-hoc test, 
$p=0.020$ compared to vehicle treated group) However, animals treated with vehicle (StudentNewman-Keuls post-hoc test, $p<0.001$ ) and ketamine $45 \mathrm{mg} / \mathrm{kg}$ (Student-Newman-Keuls post-hoc test, $p=0.040$ ) presented an increase in the immobility time between the first and second swimming session, which was not shown in the animals treated with ketamine $30 \mathrm{mg} / \mathrm{kg}$ (StudentNewman-Keuls post-hoc test, $p=0.487$ ) (Figure 2). Given that ketamine $30 \mathrm{mg} / \mathrm{kg}$ dose was the only one that induced a statiscally significant change in animals behavior, this dose was chosen for different periods of treatment evaluation.

Analyzing the data of animals treated with ketamine $30 \mathrm{mg} / \mathrm{kg} /$ day for 1,5 or 14 days, ketamine induced a reduction on the immobility time of these animals in the second swimming session $\left(16^{\text {th }}\right.$ day) depending on the duration of treatment. This reduction reaches statistical significance only on those animals treated for 14 days (One-way ANOVA, $F_{(3,45)}=3.071, p=0.038$, Student-Newman-Keuls post-hoc test, $p=0.031$ ) (Figure 3). To investigate the persistence of the antiimmobility effect of ketamine, animals were subject to swimming sessions repeatedly after the end of the treatment. The results show that ketamine's effect is not persistent, since it is already absent three days after treatment interruption $\left(18^{\text {th }}\right.$ day, Student's t test, $t=0.271, p=0.789)$. The behavior of vehicle and ketamine treated animals is similar from $18^{\text {th }}$ to $36^{\text {th }}$ day (Student's t test, $22^{\text {th }}$ day: $t=$ $0.128, p=0.899 ; 29^{\text {th }}$ day: $t=0.068, p=0.946 ; 36^{\text {th }}$ day: $t=0.615, p=0.545)$ (Figure 4).

\section{KETAMINE REPEATED TREATMENT EFFECT ON LOCOMOTION IN RESPONSE TO NOVELTY}

Hyperactivity due to exposition to a novel environment has been considered one of the few behaviors related to schizophrenia positive symptoms that can be assessed in animal models (Powell and Miyakawa 2006). Furthermore, the effect of drugs on the forced swimming can be

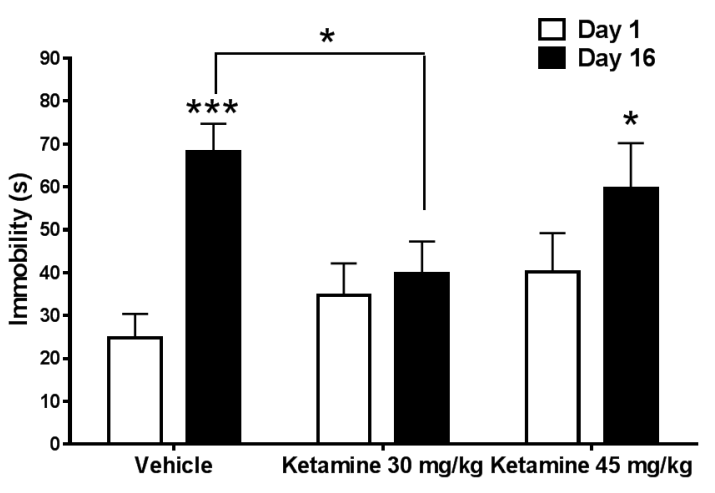

Figure 2 - Ketamine $30 \mathrm{mg} / \mathrm{kg} /$ day i.p. for 14 days decreases the immobility time of animals on the forced swimming test. Results are expressed as mean \pm S.E.M $(\mathrm{n}=8-12)$. ${ }^{* * *} p<$ $0.001,{ }^{*} p<0.05$ on the post-hoc test.

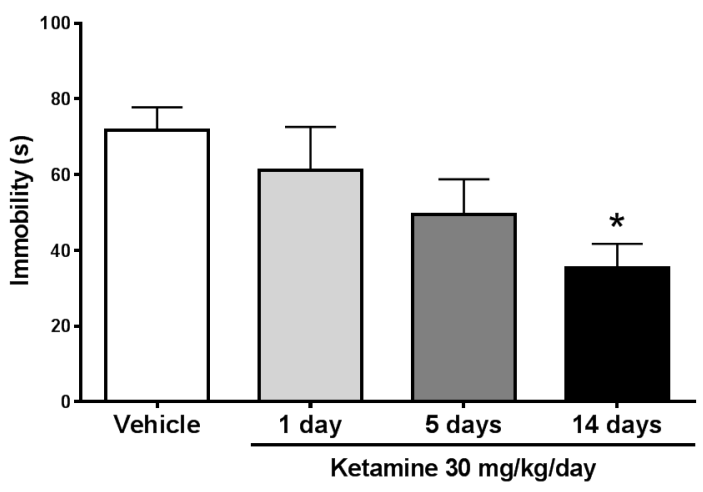

Figure 3 - Ketamine $30 \mathrm{mg} / \mathrm{kg} /$ day i.p. decreases the immobility time of animals on the forced swimming test only when administered for 14 days. Results are expressed as mean \pm S.E.M $(\mathrm{n}=11-12) .{ }^{*} p<0.05$ on the post-hoc test.

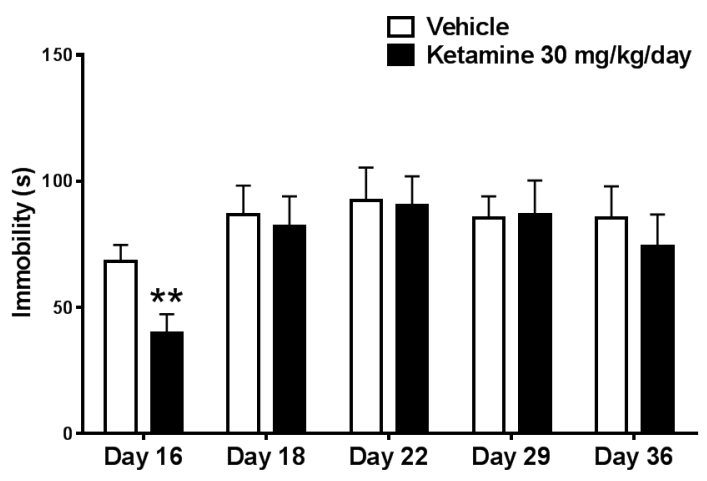

Figure 4 - Anti-immobility effect of ketamine $30 \mathrm{mg} / \mathrm{kg} /$ day i.p. (14 days) is not persistent. Results are expressed as mean \pm S.E.M $(\mathrm{n}=12) .{ }^{* *} p<0.01$ on Student's t test. 
interpreted on different ways. Stimulants or central depressants drugs often alter the immobility time in a non-specific manner and can lead to a misinterpretation of the results. Thus, the effect of ketamine repeated treatment on animal's locomotion was also evaluated (Table I). A significant effect of animals manipulation was found in horizontal (One-way ANOVA, $F_{(2,26)}=5.507, p=0.011$ ) and vertical exploration parameters (One-way ANOVA, $\left.F_{(2,26)}=7.559, p=0.003\right)$, but not for groomings (One-way ANOVA, $F_{(2,26)}=0.828$, $p=0.449$ ). A significant decrease on crossings (Student-Newman-Keuls post-hoc test, $p=0.016$ ) and rearings (Student-Newman-Keuls post-hoc test, $p=0.002$ ) was found in mice treated with ketamine when compared to sham group. However, it was also found a significant difference between vehicle and sham groups (Student-Newman-Keuls post-hoc test, crossings: $p=0.012$, rearings: $p=$ $0.014)$. This can be interpreted as a higher stress response to a new environment by the sham group since these animals were less stressed during the manipulation period when compared with injected animals. No significant differences on the evaluated parameters between saline and ketamine treated animals were found (Student-Newman-Keuls posthoc test, crossings: $p=0.535$, rearings: $p=0.259$ ). Besides the differences in locomotion, immobility time in the forced swimming session on day 16 of the sham group did not differ from vehicle group (data not shown).

\section{KETAMINE REPEATED TREATMENT EFFECT ON NOVEL OBJECT RECOGNITION}

NMDA receptor antagonists are also used to induce cognitive impairments related to schizophrenia symptoms in rodents. Thus, the effect of ketamine repeated treatment on the novel object recognition task was also evaluated. In the acquisition trial, all animals explored equally the two identical objects (Paired Student's test, Sham: $t=1.410, p$ $=0.201$; Vehicle: $t=0.214, p=0.816$; Ketamine:
TABLE I

\begin{tabular}{|c|c|c|c|}
\hline \multicolumn{4}{|c|}{$\begin{array}{l}\text { Spontaneous locomotion evaluated before the second } \\
\text { exposition to the forced swimming }\left(16^{\text {th }} \text { day). }\right.\end{array}$} \\
\hline Parameter & Sham & Vehicle & Ketamine \\
\hline & $(n=08)$ & $(n=09)$ & $\begin{array}{c}30 \mathrm{mg} / \mathrm{kg} / \mathrm{day} \\
(\mathrm{n}=10)\end{array}$ \\
\hline Crossings & $422 \pm 103$ & $260 \pm 91 *$ & $291 \pm 121 *$ \\
\hline Rearings & $106 \pm 34$ & $69 \pm 25^{*}$ & $54 \pm 26^{* *}$ \\
\hline Groomings & $7 \pm 4$ & $10 \pm 3$ & $8 \pm 4$ \\
\hline
\end{tabular}

Mean ( $\pm \mathrm{SD})$ of crossings, rearings and groomings. ${ }^{*} p<0.01$, $*_{p}<0.050$ on the post-hoc test when compared to Sham group.

$t=0.272, p=0.791)$ (data not shown). Two intervals of memory retention were assessed on the same animals: short term memory (ninety minutes after the acquisition trial) and long term memory (24h after the acquisition trial, including a reconsolidation step). On the short term memory assessment, only the animals that were not subject to any treatment (sham group) retained the memory of the familiar object by spending more time exploring the new one (Paired Student's t test, $t$ $=-3.463, p=0.013$ ) (Figure 5a). One unexpected result was the impairment on short term memory observed in the vehicle group (Paired Student's t test, $t=0.211, p=0.839$ ) (Figure 5a). However, in the long term memory assessment, both sham (Paired Student's t test, $t=-3.855, p=0.008$ ) and vehicle (Paired Student's t test, $t=-3.102, p$ $=0.015)$ groups remembered the familiar object (Figure 5b). In this trial, the amnesic effect of ketamine becomes even more evident by the lack of difference on time exploring the novel and the familiar object (Paired Student's t test, $t=0.191, p$ $=0.853$ ) (Figure 5b).

\section{DISCUSSION}

In this work we demonstrated that repeated treatment with ketamine $(30 \mathrm{mg} / \mathrm{kg} /$ day i.p. for 14 days) induced a decrease in the immobility time of mice exposed to forced swim and that this effect is 
a

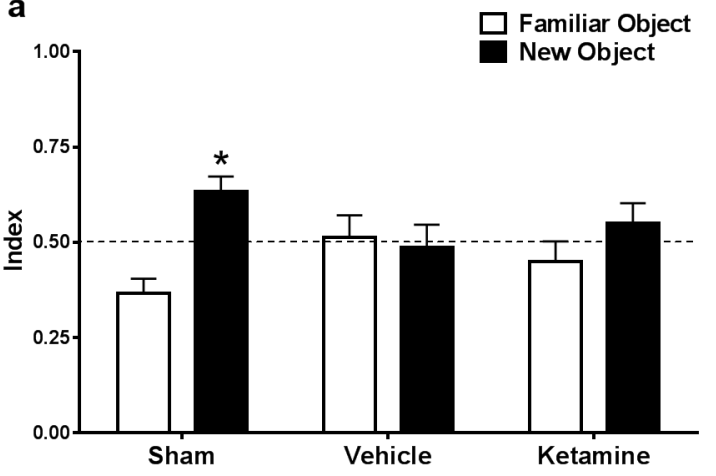

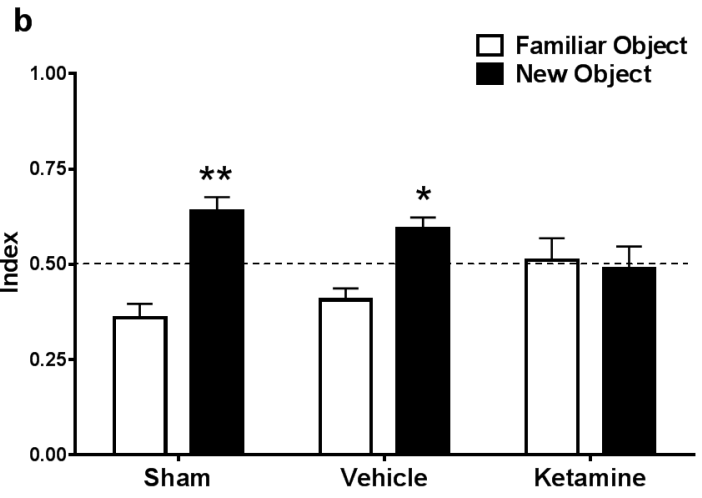

Figure 5 - Amnesic effect of ketamine (30 mg/kg/day i.p. 14 days) in the novel object recognition task. Results are expressed as mean \pm S.E.M $(\mathrm{n}=7-10)$. a) Short term memory (90 min interval). b) Long term memory $(24 \mathrm{~h}$ interval $) * p<0.05, * * p<0.01$ on Paired Student's t test.

not long lasting, since it is absent just three days after treatment interruption. Given that ketamine administration induced an anti-immobility effect without altering mice locomotion, we can assume that, in our experimental conditions, this drug induced an antidepressant-like effect.

The antidepressant effect of sub-anesthetic doses of ketamine has been demonstrated in several studies in mice (Maeng et al. 2008, Popik et al. 2008, Silva et al. 2010), rats (Akinfiresoye and Tizabi 2013, Fraga et al. 2013, Garcia et al. 2008a, b, 2009, Li et al. 2010, Parise et al. 2013, Popik et al. 2008, Reus et al. 2011, 2013, Tizabi et al. 2012, Yang et al. 2012) and humans (Maeng and Zarate 2007, Rot et al. 2010, 2012, Zarate et al. 2006), and the investigation of its mechanism of action or even the involvement of active metabolites is an active field of research ( $\mathrm{Li}$ et al. 2010, Newport et al. 2015, Zanos et al. 2016). Contrary to our results, there are few works successfully describing the use of ketamine repeated treatment to mimic schizophrenia negative symptoms in the forced swimming. Chindo et al. (2012) demonstrated an increase in the immobility time of Wistar rats that received ketamine 30 or $50 \mathrm{mg} / \mathrm{kg} /$ day i.p. for 10 days and that this effect persisted until 21 days after treatment. This ketamine effect was inhibited by clozapine and risperidone, but not by haloperidol.
Using mice, other authors have demonstrated that repeated treatment with ketamine induces a persistent increase in the immobility time only when administered at a high (anesthetic) dose (100 $\mathrm{mg} / \mathrm{kg}$, i.p) (Chatterjee et al. 2011, Hou et al. 2013, Moghaddam et al. 2014). However, there are studies conducted in rats that corroborate our findings. The first one used male Wistar rats and demonstrated that ketamine $50 \mathrm{mg} / \mathrm{kg} /$ day i.p. for 14 days induced a decrease on animals' immobility time, which is not persistent after treatment interruption (Popik et al. 2008). The second one showed an anti-immobility effect of ketamine 0.5 and $2.5 \mathrm{mg} / \mathrm{kg} /$ day i.p. for 10 days in female Wistar Kyoto rats, which is still detectable one week after treatment (Tizabi et al. 2012). Parise et al. (2013) also reported a decrease in the immobility behavior without effect on locotomotion in animals treated with ketamine 20 $\mathrm{mg} / \mathrm{kg}$ i.p. twice a day for 15 days. Furthermore, Li et al. (2010) demonstrated that acute administration of increasing doses of ketamine suppresses its own anti-immobility effect. A similar effect can be also seen in our results (absence of effect with $45 \mathrm{mg}$ / $\mathrm{kg}$ /day i.p.).

Besides the nature of the effect (i.e., increase or decrease in the immobility time), controversial results can also be found concerning the duration of ketamine effect. Our results demonstrated a not persistent 
antidepressant-like effect for this drug. However, some studies in mice report the long lasting effects of ketamine even after a single administration (Maeng et al. 2008, Tizabi et al. 2012). It's important to consider that in our work, the persistence of ketamine's effect was evaluated in the same animals repeatedly forced to swim. Using this experimental approach, we observed an increase in mice immobility throughout the days. Similar results were reported elsewhere (Borsini et al. 1986, Masuda et al. 2001, Parra et al. 1999, West 1990, de Kloet and Molendijk 2016) and lead to the proposition that, after repeated swimming, animals adapt to the forced swimming exposure and become immobile faster and for a longer period. Thus, the involvement of cognitive function (memory and learning) as well as strategies of coping with stress in the development of this behavior cannot be discharged. Although our results show mice adaptation to the forced swimming exposure, it is not likely that this phenomenon have masked the persistence of ketamine's effect since other groups successfully used similar experimental designs. For example, Tizabi et al. (2012) demonstrated the persistence of ketamine antidepressant-like effect after repeated administration in rats exposing the same animals repeatedly to forced swimming. Futhermore, in their first studies Noda et al. (1995) showed the persistence of phencyclidine proimmobility effect using the same experimental design as our, and similar results were also described for MK-801 (Langen et al. 2012) and even for the high ketamine dose (Chatterjee et al. 2012).

Divergence between our results with ketamine and those first reported by Noda et al. (1995) for phencyclidine repeated administration may be explained by the different profiles of action of these drugs on the neurotransmitter systems most commonly associated with behavioral alterations in the forced swimming, as well as with the symptoms of major depression and schizophrenia. Despite the pharmacological similarity between these two compounds, some important differences are reported. Phencyclidine and ketamine act as non-competitive NMDAR antagonists, are $\mathrm{D}_{2}$ receptors partial agonists and show dopamine reuptake inhibitory activity. However, they differ in their affinity for several receptors, such as NMDAR, $5-\mathrm{HT}_{2 \mathrm{~A}}$ and $\mathrm{D}_{2}$, resulting in distinct selectivity profiles. Ketamine has similar affinity for $\mathrm{D}_{2}$ and $\operatorname{NMDAR}\left(K_{\mathrm{i}}=0.5 \mu \mathrm{M}\right)$, which are 30 fold higher than its affinity for $5-\mathrm{HT}_{2 \mathrm{~A}}$ receptors $\left(K_{\mathrm{i}}=15 \mu \mathrm{M}\right)$. In contrast, phencyclidine has higher affinity for NMDAR and $5-\mathrm{HT}_{2 \mathrm{~A}}$ receptors $\left(K_{\mathrm{i}}=2\right.$ and $5 \mu \mathrm{M}$, respectively) than for $\mathrm{D}_{2}$ receptors $\left(K_{\mathrm{i}}=37 \mu \mathrm{M}\right)$ (Dersch et al. 1994, Kapur and Seeman 2002, Nishimura et al. 1998, Seeman et al. 2005). Animals treated during 14 days with phencyclidine ( $10 \mathrm{mg} / \mathrm{kg} /$ day s.c.), in addition to the increase in immobility time in forced swimming, showed an imbalance of dopaminergic and serotonergic systems in the frontal cortex characterized by a stimulation of the serotonergic neurotransmission and inhibition of the dopaminergic neurotransmission (Jentsch et al. 1998, Noda et al. 2000). The stimulation of serotonergic neurotransmission appears to have an important role in the pro-immobility effect induced by the repeated treatment with phencyclidine, since only second generation antipsychotics (with considerable affinity for $5-\mathrm{HT}_{2 \mathrm{~A}}$ ) are able to reverse this effect (Noda et al. 2000). On the other hand, ketamine repeated treatment is able to induce an increase in serotonergic and dopaminergic neurotransmissions in rodents' frontal cortex (Lindefors et al. 1997) and striatum (Chatterjee et al. 2012). It is known that substances able to stimulate dopaminergic neurotransmission have significant antiimmobility effect in the forced swimming (Vaugeois et al. 1996, Viana et al. 2005). Thus, this different pattern of action of sub-anesthetic doses of ketamine and PCP upon dopaminergic neurotransmission might be responsible for the opposite effects induced by these drugs in the forced swimming.

Although differences in the experimental protocols used cannot be ruled out, the nature and the persistence of ketamine repeated treatment effects on forced swimming seem to be dependent on dose and animal species used, generating controversial results. This dual effect of this drug has been discussed elsewhere (Fraga et al. 2013, Neill et al. 2014). Some authors propose that it can be 
attributed to the blockade of NMDAR composed by different patterns of subunits (GluN2a vs. GluN2b) (Jiménez-Sánchez et al. 2014) while others attribute it to an increase in glutamate efflux in cortical areas and a consequent activation of AMPA receptors leading to modulation of non-classical signaling pathways such as the GSK3/ $\beta$-catenin (Maeng et al. 2008, Beurel et al. 2016). Thus, considering the use of the forced swimming in a drug development program aiming new antipsychotics development, this bias could compromise results interpretation. Therefore, taking into account the failure of ketamine to induce an increase in immobility time in our experimental conditions, we propose that the immobility time in the forced swimming is not a good endpoint for modeling negative symptoms in NMDAR antagonist animal models of schizophrenia.

Another test that is being used to characterize animal models of schizophrenia and to evaluate compounds aimed to improve cognitive deficits in schizophrenia is the novel object recognition task. This behavioral test has been considered to have higher translational and face validity for schizophrenia than the immobility in the forced swimming, since recognition memory is impaired in schizophrenic patients (Gabrovska et al. 2003, Neill et al. 2010). We demonstrated that repeated administration of a sub-anesthetic dose of ketamine caused impairment in this task, even after memory reconsolidation of the familiar object (presentation of the familiar object twice to the same animals). This is in line with other studies demonstrating that acute administration of low dose ketamine impairs the recognition of the novel object both in rats (Boutadakis and Pitsikas 2010, Georgiadou et al. 2014, Goulart et al. 2010, Nikiforuk et al. 2013, Pitsikas et al. 2008) and mice (Chan et al. 2008, 2012), as well as in other tasks of learning and memory (Imre et al. 2006, Moghaddam et al. 1997, Moosavi et al. 2012, Uchihashi et al. 1994, Wang et al. 2006). As far as we know, only two studies beside ours presented the results of ketamine repeated administration on this task in rodents. Jacklin et al. (2012) reported a deficit in novel object recognition paradigm in Long Evans rats using a sub-anesthetic ketamine dose $(30 \mathrm{mg} / \mathrm{kg}$ i.p. twice a day for 10 days) that corroborate our findings. In contrast, Hou et al. (2013) showed that repeated administration of a high dose of ketamine $(100 \mathrm{mg} / \mathrm{kg}$ i.p. - the same that increases immobility time) did not alter novel object exploration index in Swiss-Kunming mice. Neill et al. (2014) already propose that the effects of NMDAR antagonists repeated exposure on tasks used to evaluate anhedonia and emotional blunting in rodents requires higher doses than those used to induce other behavioral impairments related to schizophrenia and our data seems to be in agreement with this assumption.

Interestingly, non-treated animals (sham) presented a higher stress-induced hyperlocomotion due to novel environment exposition when compared to vehicle or ketamine groups, which can be interpreted as a higher sensitivity to mild stressful conditions. Furthermore, we demonstrated an impairment on short term memory for the vehicle treated group, which indicates a deleterious effect induced by repeated stress that could be related to daily intraperitoneal injections or to the combination of the treatment schedule and the forced swimming in mice (Drude et al. 2011). Similar effect was observed with restraint stress (Bowman et al. 2009). However, these observations did not compromise the demonstration of the absence of hyperlocomotion and the presence of a cognitive deficit induced by ketamine, since after memory reconsolidation (long term memory evaluation) vehicle treated mice remembered the familiar object. Thus, our data confirm the usefulness of repeated subanesthetic ketamine to induce cognitive impairments relevant to model schizophrenia symptoms in rodents and corroborate the use of this pharmacological approach as a useful animal model to study some aspects of this disease (Becker et al. 2003, Neill et al. 2010). Moreover, memory tasks must be of higher relevance in drug development studies since they do not have the bias that underlies the forced swimming behavior.

In summary, ketamine $(30 \mathrm{mg} / \mathrm{kg} /$ day i.p. for 14 days) induced a decrease in the immobility time of mice forced to swim that is not related to hyperactivity. 
This confirms the antidepressant-like effect of ketamine in this behavioral task. Otherwise, impairment in the novel object recognition test was induced by the same treatment condition. Thus, in our experimental conditions ketamine induced antidepressant-like and amnesic-like effects. Considering this data, we can propose that the immobility time in the forced swimming test do not seems to be a good endpoint to evaluate the modeling of negative symptoms in NMDAR antagonist animal models of schizophrenia.

\section{ACKNOWLEDGMENTS}

The authors gratefully acknowledge Coordenação de Aperfeiçoamento de Pessoal de Nível Superior (CAPES) and Fundação de Amparo à Pesquisa do Estado do Rio Grande do Sul (FAPERGS) founding agencies for the graduate and undergraduate students fellowships and finatial support, and to the Programa de Pós-Graduação em Ciências Farmacêuticas (PPGCF-UFRGS) and Programa de Pós-Graduação em Ciências Biológicas: Neurociências (PPGNeuro-UFRGS).

\section{REFERENCES}

ABEL EL AND HANNIGAN JH. 1992. Effects of chronic forced swimming and exposure to alarm substance: Physiological and behavioural consequences. Physiol Behav 52: 781-785.

ADLER CM, MALHOTRA AK, ELMAN I, GOLDBERG T, EGAN M, PICKAR D AND BREIER A. 1999. Comparison of ketamine-induced thought disorder in healthy volunteers and though disorders in schizophrenia. Am J Psychiatry 156: 1646-1649.

AKINFIRESOYE L AND TIZABI Y. 2013. Antidepressant effects of AMPA and ketamine combination: role of hippocampal BDNF, synapsin, and mTOR. Psychopharmacol 230: 291-298.

BECKER A AND GRECKSCH G. 2004. Ketamine-induced changes in rat behaviour: a possible model of schizophrenia. Test of predictive validity. Prog Neuropsychopharmacol Biol Psychiatry 28: 1267-1277.

BECKER A, PETERS B, SCHOROEDER H, MANN T, HUETHER G AND GRECKSCH G. 2003. Ketamineinduced changes in rat behaviour: a possible model of schizophrenia. Prog Neuropsychopharmacol Biol Psychiatry 27: 687-700.
BEUREL E, GRIECO SF, AMADEI C, DOWNEY K AND JOPE RS. 2016. Ketamine-induced inhibition of glycogen synthase kinase-3 contributes to the augmentation of $\alpha$-amino-3-hydroxy-5-methylisoxazole-4-propionic acid (AMPA) receptor signaling. Bipolar Disord 18: 473-480.

BORSINI F, VOLTERRA G AND MELI A. 1986. Does the behavioral "despair" test measure "despair"? Physiol Behav 38: 385-386.

BORSOI M, ANTONIO CB, VIANA AF, NARDIN P, GONÇALVES CAAND RATES SMK. 2015a. Immobility behavior during the forced swim test correlates with BNDF levels in the frontal cortex, but not with cognitive impairments. Physiol Behav 140: 79-88.

BORSOI M ET AL. 2015b. Repeated forced swimming impairs prepulse inhibition and alters brain-derived neurotrophic factor and astroglial parameters in rats. Pharmacol Biochem Behav 128: 50-61.

BOUTADAKIS A AND PITSIKAS N. 2010. Effects of the nitric oxide synthase inhibitor L-NAME on recognition and spatial memory deficits produced by different NMDA receptor antagonists in the rat. Neuropsychopharmacol 35: 2357-2366.

BOWMAN RE, MICIK R, GAUTREAUX C, FERNANDEZ L AND LUINE VN. 2009. Sex-dependent changes in anxiety, memory and monoamines following one week of stress. Physiol Behav 97: 21-29.

BRASIL. 2013. Ministério da Ciência, Tecnologia e Inovação. Conselho Nacional de Controle de Experimentação Animal. Diretriz Brasileira para o Cuidado e a Utilização de Animais para Fins Científicos e Didáticos - DBCA. Brasília, $50 \mathrm{p}$.

BUBENIKOVA-VALESOVA V, HORACEK J, VRAJOVA M AND HOSCHL C. 2008. Models of schizophrenia in humans and animals based on inhibition of NMDA receptors. Neurosc Biobehav Rev 32: 1014-1023.

CHAN M, CHIU P, LIN C AND CHEN H. 2012. Inhibition of glycogen synthase kinase-3 attenuates psychotomimetic effects of ketamine. Schizophr Res 136: 96-103.

CHAN M, CHIU P, SOU J AND CHEN H. 2008. Attenuation of ketamine-evoked behavioral responses by mGluR5 positive modulators in mice. Psychopharmacol 198: 141148.

CHATTERJEE M, GANGULY S, SRIVASTAVA M AND PALIT G. 2011. Effect of 'chronic' versus 'acute' ketamine administration and its 'withdrawal' effect on behavioural alterations in mice: implication for experimental psychosis. Behav Brain Res 216: 247-254.

CHATTERJEE M, VERMA R, GANGULY S AND PALIT G. 2012. Neurochemical and molecular characterization of ketamine-induced experimental psychosis model in mice. Neuropharmacol 63: 1161-1171.

CHINDO BA, ADZU B, YAHAYA TA AND GAMANIEL KS. 2012. Ketamine-enhanced immobility in forced swimming 
test: a possible animal model for the negative symptoms of schizophrenia. Prog Neuro-Psychopharmacol Biol Psychiatry 38: 310-316.

CORBETT R, ZHOUL, SORENSEN SMAND MONDADORI C. 1999. Animal models of negative symptoms: M100907 antagonizes PCP-induced immobility in a forced swim test in mice. Neuropsychopharmacol 21: S211-218.

COYLE JT. 2012. NMDA receptor and schizophrenia: a brief history. Schizophr Bull 38: 920-926.

DE KLOET ER AND MOLENDIJK ML. 2016. Coping with the forced swim stressor: Towards understanding an adaptive mechanism. Neural Plast 2016: 6503162.

DERSCH CM, AKUNNE HC, PARTILLA JS, CHAR GU, DE COSTA BR, RICE KC, CARROLL FI AND ROTHMAN RB. 1994. Studies of the biogenic amine transporters: 1. Dopamine reuptake blockers inhibit $\left[{ }^{3} \mathrm{H}\right]$-mazindol binding to the dopamine transporter by competitive mechanism: preliminary evidence for different binding domains. Neurochem Res 19: 201-208.

DRUDE S, GEISSLER A, OLFE J, DOMANSKA G, SCHUETT C AND KIANK-NUSSBAUM C. 2011. Side effects of control treatment can conceal experimental data when studying responses to injection and psychological stress in mice. Lab Animal 40: 119-128.

FRAGA DB, REUS GZ, ABELAIRA HM, DE LUCA R, CANEVER L, PFAFFENSELLER B, COLPO GD, KAPCZINSKI F, QUEVEDO J AND ZUGNO AI. 2013. Ketamine alters behavior and decreases BDNF levels in the rat brain as a function of time after drug administration. Rev Bras Psiquiatria 35: 262-266.

GABROVSKA VS, LAWS KR, SINCLAIR J AND MCKEENA PJ. 2003. Visual object processing in schizophrenia: evidence for an associative agnostic effect. Schizophr Res 59: 277-286.

GARCIA LS, COMIM CM, VALVASSORI SS, RÉUS GZ, ANDREAZZA AC, STERTZ L, FRIES GR, GAVIOLI EC, KAPCZINSKI F AND QUEVEDO J. 2008b. Chronic administration of ketamine elicits antidepressant-like effects in rats without affecting hippocampal brain-derived neurotrophic factor protein levels. Basic Clin Pharmacol Toxicol 103: 502-506.

GARCIA LSB ET AL. 2008a. Acute administration of ketamine induces antidepressant-like effects in the forced swimming test and increases BDNF levels in the rat hippocampus. Prog Neuro-Psychopharmacol Biol Psychiatry 32: 140144.

GARCIA LSB, COMIM CM, VALVASSORI SS, RÉUS GZ, STERTZ L, KAPCZINSKI F, GAVIOLI EC AND QUEVEDO J. 2009. Ketamine treatment reverses behavioral and physiological alterations induced by chronic mild stress in rats. Prog Neuro-Psychopharmacol Biol Psychiatry 33: 450-455.
GEORGIADOU G, GRIVAS V, TARANTILIS PA AND PITSIKAS N. 2014. Crocins, the active constituents of Crocus Sativus L., counteracted ketamine-induced behavioural deficits in rats. Psychopharmacol 231: 717726.

GOULART BK, LIMA MNM, FARIAS CB, REOLON GK, ALMEIDA VR, QUEVEDO J, KAPCZINSKI F, SCHRÖDER N AND ROESLER R. 2010. Ketamine impairs recognition memory consolidation and prevents learning-induced increase in hippocampal brain-derived neurotrophic factor levels. Neurosci 167: 969-973.

HOU Y, ZHANG H, XIE G, CAO X, ZHAO Y, LIU Y, MAO Z, YANG J AND WU C. 2013. Neuronal injury, but not microglia activation, is associated with ketamineinduced experimental schizophrenic model in mice. Prog Neuropsychopharmacol Biol Psychiatry 45C: 107-116.

IMRE G, FOKKEMA DS, DEN BOER JA AND TER HORST GJ. 2006. Dose-response characteristics of ketamine effect on locomotion, cognitive function and central neuronal activity. Brain Res Bull 69: 338-345.

JACKLIN DL, GOEL A, CLEMENTINO KJ, HALL AWM, TALPOS JC AND WINTERS BD. 2012. Severe cross modal object recognition deficits in rats treated sub-chronically with NMDA receptor antagonists are reversed by systemic nicotine: Implications for abnormal multisensory integration in schizophrenia. Neuropsychopharmacol 37: 2322-2331.

JENTSCH JD, DAZZI L, CHHATWAL JP, VERRICO CD AND ROTH RH. 1998. Reduced prefrontal cortical dopamine, but not acetylcholine, release in vivo after repeated, intermittent phencyclidine administration to rats. Neurosci Lett 258: 175-178.

JIMÉNEZ-SÁNCHEZ L, CAMPA L, AUBERSON YP AND ADELL A. 2014. The role of GluN2A and GluN2B subunits on the effects of NMDA receptor antagonists in modeling schizophrenia and treating refractory depression. Neuropsychopharmacol 39: 2673-2680.

KANTROWITZ J AND JAVITT DC. 2012. Glutamatergic transmission in schizophrenia: from basic research to clinical practice. Curr Opin Psychiatry 25: 96-102.

KAPUR S AND SEEMAN P. 2002. NMDA receptor antagonists ketamine and PCP have direct effects on the dopamine $\mathrm{D}_{2}$ and serotonin 5- $\mathrm{HT}_{2}$ receptors-implicated for models of schizophrenia. Mol Psychiatry 7: 837-844.

KAWAURA K, KARASAWA J AND HIKICHI H. 2016. Stimulation of the metabotropic glutamate (mGlu) 2 receptor attenuates the MK-801-induced increase in the immobility time in the forced swimming test in rats. Pharmacol Rep 68: 80-84.

KAWAURA K, KOIKE H, KINOSHITA K, KAMBE D, KAKU A, KARASAWA J, CHAKI S AND HIKICHI H. 2015. Effects of a glycine transporter-1 inhibitor and 
D-serine on MK-801-induced immobility in the forced swimming test in rats. Behav Brain Res 278: 186-192.

LAHTI AC, KOFFEL B, LAPORTE D AND TAMMINGA CA. 1995. Subanesthetic doses of ketamine stimulate psychosis in schizophrenia. Neuropsychopharmacol 113: 9-19.

LANGEN B, DOST R, EGERLAND U, STANGE H AND HOEFGEN N. 2012. Effect of PDE10A inhibitors on MK-801-induced immobility in the forced swim test. Psychopharmacol 221: 249-259.

LARGE C. 2007. Do NMDA receptor antagonist models of schizophrenia predict the clinical efficacy of antipsychotic drugs? J Psychopharmacol 21: 283-301.

LI N, LEE B, LIU R, BANASR M, DWYER JM, IWATA M, LI XY, AGHAJANIAN G AND DUMAN RS. 2010. mTOR-dependent synapse formation underlies the rapid antidepressant effects of NMDA antagonists. Science 329: 959-964.

LINDEFORS N, BARATI S AND O'CONNOR WTO. 1997. Differential effects of single and repeated ketamine administration on dopamine, serotonin and GABA transmission in rat medial prefrontal cortex. Brain Res 759: 205-212.

MAENG S, ZARATE CA, DU J, SCHLOESSER RJ, MCCAMMON J, CHEN G AND MANJI HK. 2008. Cellular mechanisms underlying the antidepressant effects of ketamine: role of a-amino-3-hydroxy-5methylisoxazole-4-propionic acid receptors. Biol Psychiatry 63: 349-352.

MAENG S AND ZARATE JR CA. 2007. The role of glutamate in mood disorders: results from the ketamine in major depression study and the presumed cellular mechanism underlying its antidepressant effects. Curr Psychiatry Rep 9: 467-474.

MASUDA Y, ISHIGOOKA S AND MATSUDA Y. 2001. Behaviors of mice given forced-swimming. Exp Anim 50: 331-335.

MOGHADDAM AH, SOBARZO-SÁNCHEZ E, NABAVI SF, DAGLIA M AND NABAVI SM. 2014. Evaluation of the antipsychotic effects of 2-(dimethylamino)- and 2-(methylamino)-7H-naphtho[1,2,3-de]quinolin-7-one derivatives in experimental model of psychosis in mice. Curr Top Med Chem 14: 229-233.

MOGHADDAM B, ADAMS B, VERMA A AND DARRON D. 1997. Activation of glutamatergic neurotransmission by ketamine: a novel step in the pathway from NMDA receptor blockade to dopaminergic and cognitive disruptions associated with the prefrontal cortex. J Neurosci 17: 29212927.

MOOSAVI M, KHALES GY, RASTEGAR K AND ZARIFKAR A. 2012. The effect of sub-anesthetic and anesthetic ketamine on water maze memory acquisition, consolidation and retrieval. Eur J Pharmacol 677: 107-110.
MOURI A, KOSEKI T, NARUSAWA S, NIWA M, MAMIVA T, KANO A, SAWAAAND NABESHIMA T. 2012. Mouse strain differences in phencyclidine-induced behavioural changes. Int J Neuropsychopharmacol 15: 767-779.

MURAI R, NODA Y, MATSUI K, KAMEI H, MOURI A, MATSUBA K, NITTA A, FURUKAWA H AND NABESHIMA T. 2007. Hypofunctional glutamatergic neurotransmission in the prefrontal cortex is involved in the emotional deficit induced by repeated treatment with phencyclidine in mice: implications for abnormalities of glutamate release and NMDA-CaMKII signaling. Behav Brain Res 180: 152-160.

NEILL JC, BARNES S, COOK S, GRAYSON B, IDRIS NF, MCLEAN SL, SNIGDHA S, RAJAGOPAL L AND HARTE MK. 2010. Animal models of cognitive dysfunction and negative symptoms of schizophrenia: focus on NMDA receptor antagonism. Pharmacol Ther 128: 419-432.

NEILL JC, HARTE MK, HADDAD PM, LYDALL ES AND DWYER DD. 2014. Acute and chronic effects of NMDA receptor antagonists in rodents, relevance to negative symptoms of schizophrenia: A translational link to humans. Eur Neuropsychopharmacol 24: 822-835.

NEVES G, ANTONIO CB, BETTI AH, PRANKE MA, FRAGA CAM, BARREIRO EJ, NOËL F AND RATES SMK. 2013. New insights into pharmacological profile of LASSBio-579, a multi-target $N$-phenylpiperazine derivative active on animal models of schizophrenia. Behav Brain Res 237: 86-95.

NEWPORT DJ, CARPENTER LL, MCDONALD WM, POTASH JB, TOHEN M, NEMEROFF CB, APA COUNCIL OF RESEARCH TASK FORCE ON NOVEL BIOMARKERS AND TREATMENTS. 2015. Ketamine and other NMDA antagonists: early clinical trials and possible mechanisms in depression. Am J Psychiatry 172: 950-966.

NIKIFORUK A, KOS T, FIJAŁ K, HOŁUJ M, RAFA D AND POPIK P. 2013. Effects of the selective 5-HT receptor antagonist SB-269970 and amisulpride on ketamine-induced schizophrenia-like deficits in rats. PLoS One 8: e66695.

NISHIMURA M, SATO K, OKADA T, YOSHIYA I, SCHLOSS P, SHIMADA S AND TOHYAMA M. 1998. Ketamine inhibits monoamine transporters expressed in human embryonic kidney 293 cells. Anesthesiol 88: 768744.

NODA Y, KAMEI H, MAMIYA T, FURUKAWA H AND NABESHIMA T. 2000. Repeated phencyclidine treatment induces negative symptom-like behavior in forced swimming test in mice: imbalance of prefrontal serotonergic and dopaminergic functions. Neuropsychopharmacol 23: 375-387. 
NODA Y, MAMIYA T, FURUKAWA H AND NABESHIMA T. 1997. Effects of antidepressants on phencyclidineinduced enhancement of immobility in a forced swimming test in mice. Eur J Pharmacol 324: 135-140.

NODA Y, YAMADA K, FURUKAWA H AND NABESHIMA T. 1995. Enhancement of immobility in a forced swimming test by subacute or repeated treatment with phencyclidine: a new model of schizophrenia. Br J Pharmacol 116: 25312537.

OWOLABI RA, AKANMU MA AND ADEYEMI OI. 2014. Effects of ketamine and N-methyl-D-aspartate on fluoxetine-induced antidepressant-related behavior using the forced swimming test. Neurosci Lett 566: 172-176.

PARISE EM, ALCANTARA LF, WARREN BL, WRIGHT KN, HADAD R, SIAL OK, KROECK KG, IÑIGUEZ SD AND BOLAÑOS-GUZMÁN CA. 2013. Repeated ketamine exposure induces an enduring resilient phenotype in adolescent and adult rats. Biol Psychiatry 74: 750-759.

PARRA A, VINADER-CAEROLS C, MONLEON S AND SIMON VM. 1999. Learned immobility is also involved in the forced swimming test in mice. Psicothema 11: 239246.

PIETERSEN CK, BOSKER FJ, DOORDUIN J, JONQSMA ME, POSTEMA F, HAAS JV, JOHNSON MP, KOCH T, VLADUSICH T AND DEN BOER JA. 2007. An animal model of emotional blunting in schizophrenia. Plos One 2: e1360.

PILOWSKY LS, BRESSAN RA, STONE JM, ERLANDSSON K, MULLIGAN RS, KRYSTAL JH AND ELL PJ. 2006. First in vivo evidence of an NMDA receptor deficit in medication-free schizophrenic patients. Mol Psychiatry 11: 118-119.

PITSIKAS N, BOULTADAKIS A AND SAKELLARIDIS N. 2008. Effects of sub-anesthetic doses of ketamine on rats' spatial and non-spatial recognition memory. Neurosci 154 : 454-460.

POPIK P, KOS T, SOWA-KUÉMA M AND NOWAK G. 2008. Lack of persistent effects of ketamine in rodent models of depression. Psychopharmacol 198: 421-430.

PORSOLT RD, BERTIN A AND JALFRE M. 1977. Behavioral despair in mice: a primary screening test for antidepressants. Arch Int Pharmacodyn Thèr 229: 327-336.

PORSOLT RD, MOSER PC AND CASTAGNÉ V. 2010. Behavioral indices in antipsychotic drug discovery. JPET 333: 632-638

POWELL CM AND MIYAKAWA T. 2006. Schizophreniarelevant behavioral testing in rodent models: A uniquely human disorder? Biol Psychiatry 59: 1198-1207.

RATES SMK. 1998. Efeitos comportamentais em ratos Wistar de diferentes regimes de estresse relacionados com modelos animais de depressão. Caderno de Farmácia 14: 31 .
REUS GZ ET AL. 2013. Ketamine and imipramine in the nucleus accumbens regulate histone deacetylation induced by maternal deprivation and are critical for associated behaviors. Behav Brain Res 256: 451-456.

REUS GZ, STRINGARI RB, RIBEIRO KF, FERRARO AK, VITTO MF, CESCONETTO P, SOUZA CT AND QUEVEDO J. 2011. Ketamine plus imipramine treatment induces antidepressant-like behavior and increases CREB and BDNF protein levels and PKA and PKC phosphorylation in rat brain. Behav Brain Res 221: 166171.

RODVELT KR, KRACKE GR, SCHACHTMAN TR AND MILLER DK. 2008. Ketamine induces hyperactivity in rats and hypersensitivity to nicotine in rat striatal slices. Psychopharmacol 124: 57-73.

ROT M, COLLINS KA, MURROUGH JW, PEREZ AM, REICH DL, CHARNEY DS AND MATHEW SJ. 2010. Safety and efficacy of repeated-dose intravenous ketamine for treatment-resistant depression. Biol Psychiatry 67: 139-145.

ROT M, ZARATE CA, CHARNEY DS AND MATHEW SJ. 2012. Ketamine for depression: where do we go from here? Biol Psychatry 72: 537-547.

RUNDFELDT C, SOCALA K AND WLAZ P. 2010. The atypical anxiolytic drug, tofisopam, selectively blocks phosphodiesterase isoenzymes and is active in the mouse model of negative symptoms of psychosis. J Neural Transm 117: 1319-1325.

SEEMAN P, KO F AND TALLERICO T. 2005. Dopamine receptor contribution to the action of PCP, LSD and ketamine psychotomimetics. Mol Psychiatry 10: 877-883.

SILVA FCC ET AL. 2010. Behavioral alterations and prooxidant effect of a single ketamine administration to mice. Brain Res Bull 83: 9-15.

TIZABI Y, BHATTI BH, MANAYE KF, DAS JR AND AKINFIRESOYE L. 2012. Antidepressant-like effects of low ketamine dose is associated with increased hippocampal AMPA/NMDA receptor density ratio in female Wistar-Kyoto rats. Neurosci 213: 72-80.

UCHIHASHI Y, KURIBARA H, ISA Y, MORITA T AND SATO T. 1994. The disruptive effects of ketamine on passive avoidance learning in mice: involvement of dopaminergic mechanism. Psychopharmacol 116: 40-44.

VAUGEOIS J, POUHÉ D, ZUCCARO F AND COSTENTIN J. 1996. Indirect dopamine agonists effects on despair test: dissociation from hyperactivity. Pharmacol Biochem Behav 54: 235-239.

VIANA AF, RATES SMK, NAUDIN B, JANIN F, COSTENTIN J AND DO REGO JC. 2008. Effects of acute or 3-day treatments of Hypericum caprifoliatum Cham. \& Schltdt. (Guttiferae) extract or of two established antidepressants on basal and stress-induced increase in 
serum and brain corticosterone levels. J Psychopharmacol 22: 681-690.

VIANA AF, REGO J, VON POSER G, FERRAZ A, HECKLER AP, COSTENTIN J AND RATES SMK. 2005. The antidepressant-like effect of Hypericum caprifoliatum Cham \& Schlecht (Guttiferae) on forced swimming test results from an inhibition of neuronal monoamine uptake. Neuropharmacol 49: 1042-1052.

WANG JH, FU Y, WILSON FAW AND MA YY. 2006. Ketamine affects memory consolidation: differential effects in t-maze and passive avoidance paradigms in mice. Neurosci 140: 993-1002.

WEST AP. 1990. Neurobehavioral studies of forced swimming: the role of learning and memory in the forced swim test. Prog Neuro-Psychopharmacol Biol Psychiatry 14: 863877.
YANG C, LI W, YU H, GAO Z, LIU X, ZHOU Z AND YANG J. 2012. Tramadol pretreatment enhances ketamineinduced antidepressant effects and increases mammalian target of rapamycin in rat hippocampus and prefrontal cortex. J Biomed Biotechnol 2012: ID 175619.

YUEN EY, WEI J, LIU W, ZHONG P, LI X AND YAN Z. 2012. Repeated stress causes cognitive impairment by suppressing glutamate receptor expression and function in prefrontal cortex. Neuron 73: 962-977.

ZANOS P ET AL. 2016. NMDAR inhibition-independent antidepressant actions of ketamine metabolites. Nature 533: 481-486.

ZARATE JR CA, SINGH JB, CARLSON PJ, BRUTSCHE NE, AMELI R, LUCKENBAUGH DA, CHARNEY DS AND MANJI HK. 2006. A randomized trial on an $\mathrm{N}$-methyl-D-aspartate antagonist in treatment-resistant major depression. Arch Gen Psychiatry 63: 856-864. 